\title{
THE $M_{W}$ 6.6 GISBORNE EARTHQUAKE OF 2007: PRELIMINARY RECORDS AND GENERAL SOURCE CHARACTERISATION
}

\author{
Caroline François-Holden, Stephen Bannister, John Beavan, \\ Jim Cousins, Bryan Field, Rob McCaffrey, Graeme McVerry, \\ Martin Reyners, John Ristau, Sergey Samsonov \\ and Laura Wallace ${ }^{1}$
}

\begin{abstract}
SUMMARY
Gisborne city experienced recorded peak ground accelerations exceeding $0.25 \mathrm{~g}$ for the third time since 1966 in the magnitude $\mathrm{M}_{\mathrm{w}} 6.6$ earthquake at $075516 \mathrm{UT}$ (8:55 pm local time) on 20 December 2007. The earthquake was at a hypocentral distance of $64 \mathrm{~km}$ from Gisborne at a depth of $40 \mathrm{~km}$, well within the mantle of the subducted slab of the Pacific plate as it dips beneath the North Island of New Zealand. At this location the plate interface is about $10-15 \mathrm{~km}$ deep. The main event was followed by sparse aftershocks consistent with a rupture of the subducted plate, with the largest aftershock of magnitude 4.6 occurring on December 22nd. The GeoNet website received 3,257 felt reports, with a strongest intensity of MM8 (heavily damaging) assigned to the main shock.
\end{abstract}

The 122 strong motion records of this event show a clear regional directional variation in the wave propagation, as well as a distinct $2 \mathrm{~Hz}$ peak widely observed throughout the country. At a local scale, three sites in the Gisborne region recorded accelerations around $0.2 \mathrm{~g}$. Recordings in Gisborne city also revealed a predominant displacement direction, parallel to the main street where most of the damage occurred.

Source studies from moment tensor solution, aftershock relocations, GPS and strong motion data showed that the earthquake occurred within the subducted plate on a 45 degree eastward dipping fault plane. The mainshock rupture area is about $10 \mathrm{~km}^{2}$ reaching a maximum slip of $2.6 \mathrm{~m}$. The computed high stress drop value of $17 \mathrm{MPa}$ is as expected for an intraslab event and consistent with observations of very energetic seismic waves as well as heavy structural damage.

GPS data recorded by continuous GPS instruments have also shown that slow slip occurred for about three weeks after the main shock. The slow slip was triggered on the subduction interface, rather than on the same fault plane as the aftershocks. This is the first clear-cut case worldwide of triggered slow slip, although three non-triggered slow-slip events have occurred in the same region since 2002.

\section{INTRODUCTION}

On Thursday the 20th of December 2007, at approximately $8: 55 \mathrm{pm}, \mathrm{a}_{\mathrm{w}} 6.6$ earthquake shook the North Island of New Zealand. The earthquake was very well recorded on the New Zealand GeoNet seismic network. It was located by GNS Science $50 \mathrm{~km}$ southeast of Gisborne and at a depth of $44 \mathrm{~km}$, which placed it within the subducted Pacific plate, below the depth of the plate interface $(10-15 \mathrm{~km})$.

A large number of Gisborne residents felt the earthquake, and self evacuated to higher ground to escape potential tsunami. The earthquake was felt as far north as Baddeleys Beach (north of Auckland) and as far south as Otatara (at the bottom tip of the South Island), as well as on the Chatham Islands. Shaking intensities on the Modified Mercalli scale ranged from MM8 near Gisborne to MM3 further afield. Liquefaction (sand boils and mud explosions) was observed near the Waipaoa River (Gisborne District Council via The Gisborne Herald, Figure 2) and mud volcanoes in the area showed an increase in activity. In Gisborne city, buildings were extensively damaged, including three which collapsed.
Here we present preliminary results from the study of strong motion records as well as a source characterization of the event using a variety of geophysical techniques.

\section{TECTONIC SETTING}

The North Island, New Zealand straddles the boundary zone between the Pacific and Australian tectonic plates, which converge obliquely at $\sim 40-45 \mathrm{~mm} / \mathrm{yr}$. Westward subduction of the Pacific plate occurs at the Hikurangi Trough, to the east of the North Island (Figure 1). The top of the subducted Pacific plate is at $\sim 16 \mathrm{~km}$ depth beneath the Gisborne region $[1,2]$, and is subducting beneath the northeastern North Island at a rate of $50-60 \mathrm{~mm} / \mathrm{yr}$ [3]. This is faster than the relative plate rate because the North Island of New Zealand is moving away from the Australian plate, due to extension in the Taupo Volcanic Zone and Bay of Plenty. Most of the moderate to large earthquakes in the northeastern North Island are related to Pacific plate subduction. For example, in the Gisborne region, the March and May $1947\left(\mathrm{M}_{\mathrm{W}}\right.$ 6.9-7.1) [4] and 1966 $\left(M_{W}\right.$ 5.6) [5] earthquakes occurred on the interface between the subducting and overriding plates (Figure 2).

\footnotetext{
${ }^{1}$ GNS Science, Avalon, Lower Hutt
} 


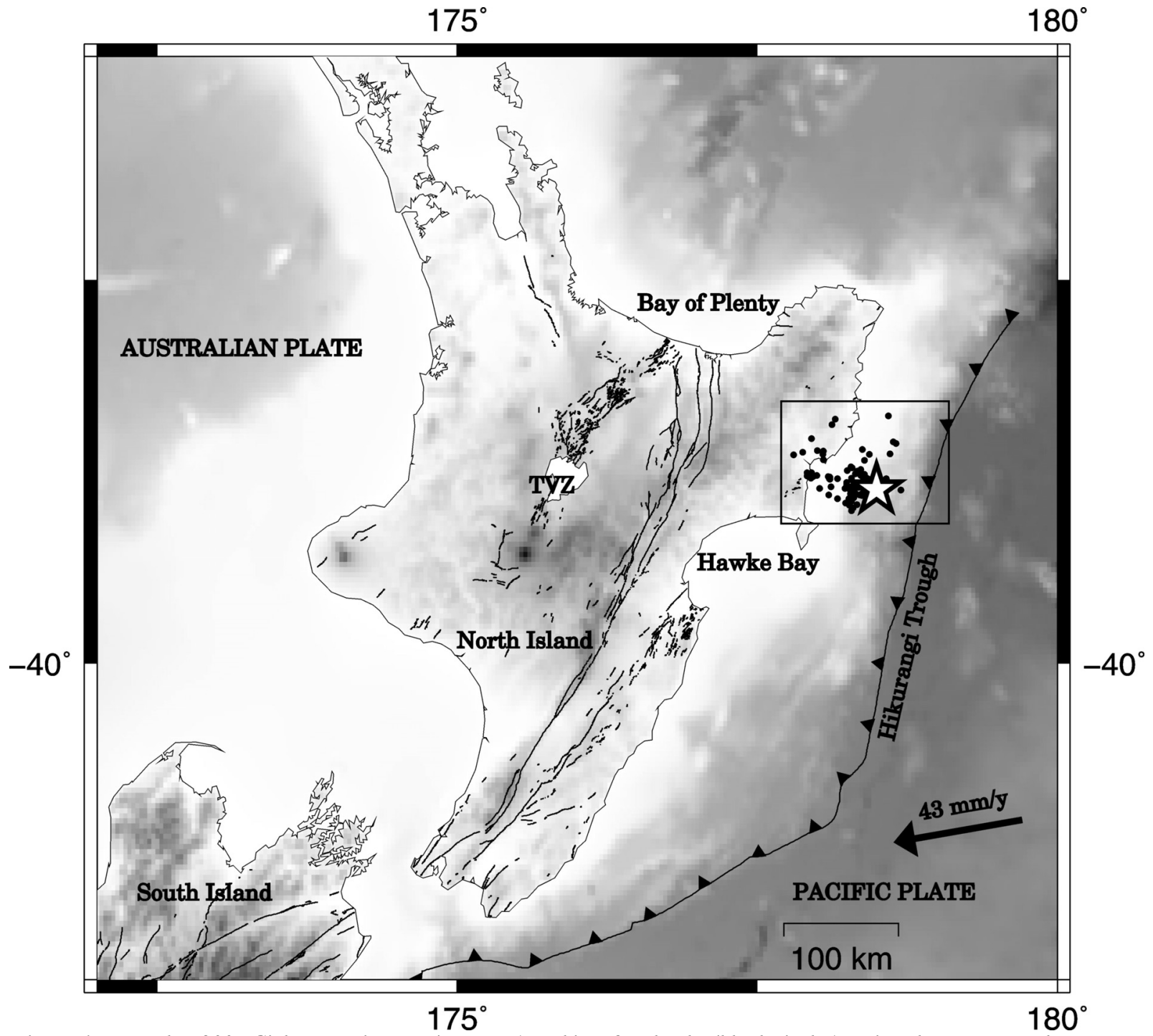

Figure 1:December 2007 Gisborne epicentre (grey star) and its aftershocks (black circles). Triangles represent the Hikurangi trench. The box delimits the detailed area in figure 2.

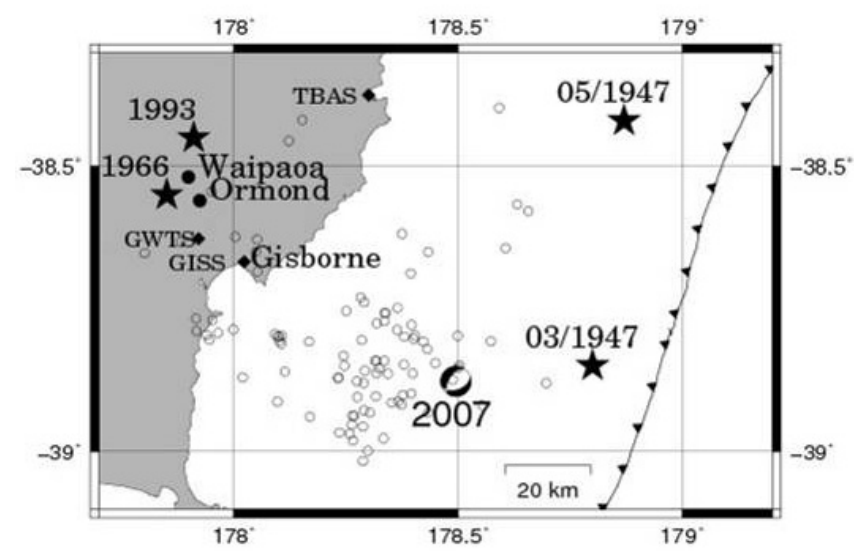

Figure 2: $\quad$ December 2007 Gisborne epicentre location and focal mechanism and its aftershocks (circles). Triangles represent the Hikurangi trench. Diamonds represent strong motion instrument locations mentioned in the strong motion instrument studies. Stars represent locations for the 1947 earthquake sequence, the 1966 Gisborne earthquake and the 1993 + Ormond earthquake.
Similar to the 2007 Gisborne earthquake, the $\mathrm{M}_{\mathrm{W}} 6.31993$ Ormond earthquake (Figure 2) occurred on a fault cutting through the subducting Pacific plate [6]. More recently, slow slip events on the subduction interface in the Gisborne region have been detected, involving intermittent accelerated slip on the subduction interface fault over a period of days to weeks [7].

\section{STRONG-MOTION MATTERS}

\section{GeoNet Response}

The Gisborne earthquake was extremely well recorded on the New Zealand GeoNet seismic network (106 out of 107 stations), and the strong motion network (75 out of 195 stations). It was felt as far north as Baddeleys Beach (north of Auckland) and as far south as Otatara (at the bottom tip of the South Island), and on the Chatham Islands. In total, the GeoNet website received 3,257 reports (electronically submitted forms) of people's experience of the earthquake. From these, shaking intensities on the Modified Mercalli scale were calculated, ranging from MM8 near Gisborne to MM3 further afield (Figure 3). In Gisborne city, buildings were extensively damaged, including three which collapsed. There was no tsunami generated (the earthquake was too small and deep), but the self evacuation by residents caused a traffic jam in the city. 


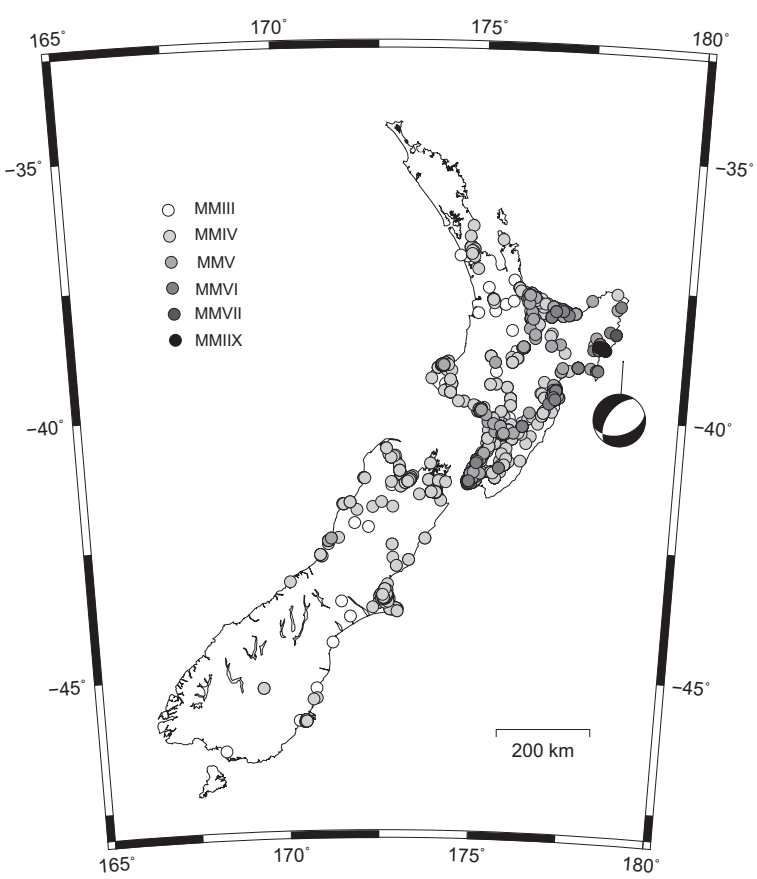

Figure 3: $\quad$ Map of the 3,257 felt reports converted into shaking intensities on the Modified Mercalli scale for the Gisborne event. Intensities range from MM3 to MM8 near Gisborne.

GeoNet Duty Seismologist, Dr. Warwick Smith, and GeoNet Project Director, Dr. Ken Gledhill, spent several hours after the mainshock dealing with the media, MCDEM (Ministry of Civil Defence and Emergency Management) and other concerned agencies. The magnitude of the earthquake was such that the NCMC (National Crisis Management Centre) in the Beehive was activated.

Since the earthquake was deeper than $40 \mathrm{~km}$, it almost certainly occurred within the mantle of the subducted slab (the depth of the plate interface at the epicentre is $15 \mathrm{~km}$ ). According to previous research [6], these earthquakes typically have poor aftershock sequences, with fewer than expected large aftershocks; this was indeed the case. This information was relayed to MCDEM, which assisted engineering assessments of damaged buildings in Gisborne.

\section{Strong motion instrument studies}

There were 260 instruments with strong-motion capability in seismic recording networks in New Zealand at the time of the $\mathrm{M}_{\mathrm{w}}$ 6.6 Gisborne earthquake. Records were returned by 122 of the instruments (Figure 4). Time-history and spectral data from the records are available as text files and pdf plots from the GeoNet ftp site ftp://ftp.geonet.org.nz/strong/processed/.

Peak ground acceleration (PGA) exceeded $0.1 \mathrm{~g}\left(981 \mathrm{~mm} / \mathrm{s}^{2}\right)$ at three locations : GISS in the Central Business District of Gisborne City $(0.28 \mathrm{~g})$, GWTS near the centre of the Waipaoa Plain about $10 \mathrm{~km}$ northwest of Gisborne $(0.19 \mathrm{~g})$ and TBAS at Tolaga Bay $(0.18 \mathrm{~g})$ (Figure 2). Records from within $250 \mathrm{~km}$ of the epicentre are listed in Table 1, and the strongest horizontal components of PGA from all records are plotted as a function of source distance in Figure 5. Also shown in Figure 5 are PGAs estimated using the attenuation model of [8]. The attenuation model was derived from data at distances of up to $400 \mathrm{~km}$. Beyond this distance, anelastic attenuation effects that are not accounted for in the subduction zone expressions may cause the model to over-estimate the data, as for the data point at over $900 \mathrm{~km}$ in Figure 5. The modelled PGAs match the recorded ones well, regarding both the attenuation with distance and the dependence on site ground class. Source distance in the [8] model is defined as the shortest distance between the recording site and the fault rupture surface. The source distances given here for the Gisborne earthquake will change slightly in future because the current ones were measured from the point closest to Gisborne, on an interim model for the rupture surface that in turn was derived from the preliminary aftershock locations.

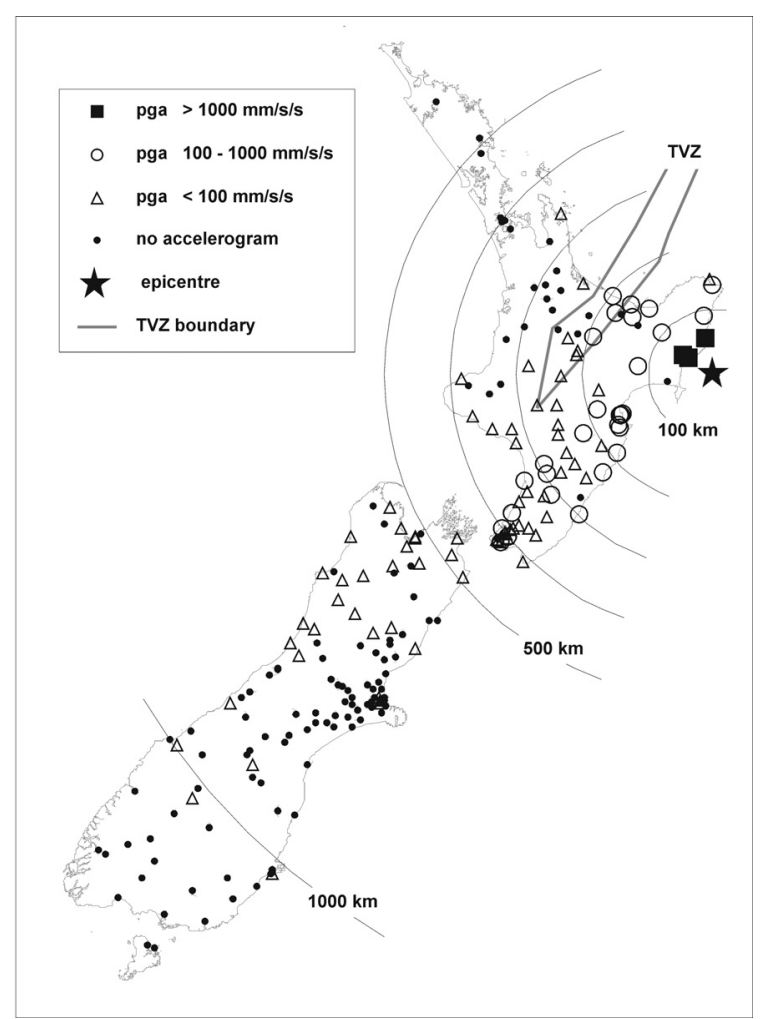

Figure 4: Locations of strong-motion sensors at the time of the Gisborne Earthquake of 20th December 2007, with peak ground acceleration levels indicated where strong-motion (acceleration) recordings were obtained. For clarity not all of the Wellington region sites are shown. Note the dearth of records from sites west of the Taupo Volcanic Zone (TVZ). More acceleration data are potentially available because 28 of the "noaccelerogram" sites are National Network sites that provided seismograph (velocity) records from the earthquake.

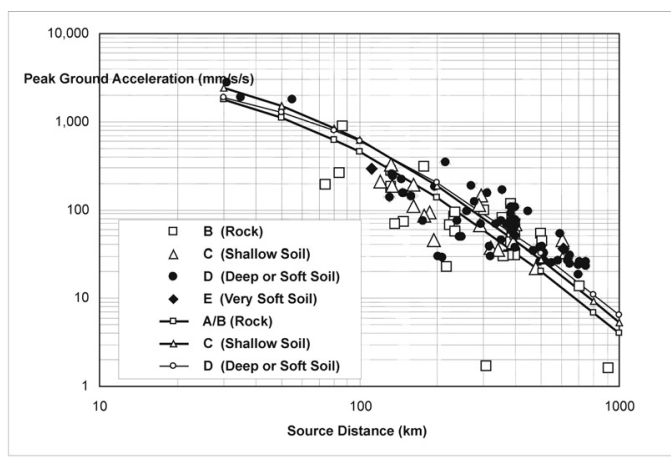

Figure 5: Peak ground accelerations recorded during the Gisborne Earthquake of 20 December 2007, compared with the attenuation model of [8]. The very low acceleration of $1.7 \mathrm{~mm} / \mathrm{s} 2$ at $308 \mathrm{~km}$ is for a site on the Coromandel Peninsula with a highly-attenuating propagation path across the full width of the TVZ. 
Table 1: Strong-motion data recorded within $250 \mathrm{~km}$ source distance of the Gisborne Earthquake of $20^{\text {th }}$ December 2007. The site classes are as defined in NZS1170.5 (Standards New Zealand, 2004)

\begin{tabular}{|c|c|c|c|c|c|c|}
\hline \multirow{2}{*}{$\begin{array}{l}\text { Source Distance } \\
\text { (approx) (km) }\end{array}$} & \multicolumn{3}{|c|}{ Peak Ground Acceleration (mm/s/s) } & \multirow{2}{*}{$\begin{array}{l}\text { Site } \\
\text { Code }\end{array}$} & \multirow{2}{*}{ Name of Recording Site } & \multirow{2}{*}{ Site Class } \\
\hline & Vert. & Horiz. 1 & Horiz. 2 & & & \\
\hline 31 & 1475 & 2574 & 2767 & GISS & Gisborne 2ZG & D-E \\
\hline 35 & 717 & 1246 & 1883 & GWTS & Gisborne Waipaoa Treatment Plant & $D-E$ \\
\hline 55 & 616 & 1209 & 1781 & TBAS & Tolaga Bay Area School & $\mathrm{D}$ \\
\hline 84 & 106 & 246 & 259 & PUZ & Puketiti & B \\
\hline 74 & 141 & 190 & 186 & MWZ & Matawai & B \\
\hline 131 & 71 & 139 & 135 & TDHS & Te Araroa District High School & $\mathrm{D}$ \\
\hline 112 & 159 & 271 & 293 & OPCS & Opotiki College & $E$ \\
\hline 138 & 42 & 69 & 69 & $M X Z$ & Matakaoa Point & B \\
\hline 132 & 105 & 327 & 234 & NAMS & Napier Museum & C \\
\hline 132 & 105 & 276 & 248 & NSPS & Napier St. Pauls & B \\
\hline 132 & 89 & 183 & 140 & NGHS & Napier Girls High & B \\
\hline 120 & 159 & 175 & 210 & RUAS & Ruatoki School & C \\
\hline 134 & 74 & 254 & 240 & $\mathrm{NCHS}$ & Napier Colenso High School & $D-E$ \\
\hline 135 & 113 & 237 & 198 & NCDS & Napier Civil Defence & D-E \\
\hline 147 & 72 & 153 & 110 & HNPS & Havelock North Primary School & $\mathrm{D}$ \\
\hline 134 & 101 & 186 & 165 & WKHS & Whakatane High School & C \\
\hline 148 & 57 & 155 & 141 & HCDS & Hastings Civil Defence Headquarters & $\mathrm{D}$ \\
\hline 148 & 31 & 73 & 62 & BKZ & Black Stump Farm & $\mathrm{B}$ \\
\hline 145 & 152 & 212 & 224 & KAFS & Kawerau Fire Station & $\mathrm{D}$ \\
\hline 161 & 97 & 191 & 161 & KFHS & Kaweka Forest Headquarters & C \\
\hline 178 & 70 & 312 & 207 & PXZ & Pawanui & B \\
\hline 159 & 55 & 91 & 143 & RPCS & Reporoa College & $\mathrm{D}$ \\
\hline 162 & 71 & 100 & 111 & MWFS & Matata Watchorn Farm & C \\
\hline 186 & 40 & 93 & 70 & WPWS & Waipawa & C \\
\hline 176 & 43 & 73 & 76 & WAIS & Wairakei & $\mathrm{D}$ \\
\hline 178 & 61 & 72 & 87 & TPPS & Taupo Police & C \\
\hline 196 & 70 & 153 & 181 & WAKS & Wakarara & $\mathrm{D}$ \\
\hline 214 & 141 & 341 & 287 & PGFS & Porangahau Fire Station & $\mathrm{D}$ \\
\hline 194 & 30 & 45 & 30 & TIRS & Tirohanga School & C \\
\hline 201 & 25 & 30 & 30 & TTHS & Tongariro High School & $\mathrm{D}$ \\
\hline 208 & 22 & 27 & 29 & TBCS & Tauranga Boys College & $\mathrm{D}$ \\
\hline 224 & 35 & 59 & 66 & THHS & Taihape Hospital & B \\
\hline 239 & 42 & 75 & 74 & WBFS & Weber Fire Station & $\mathrm{D}$ \\
\hline 235 & 50 & 94 & 89 & DVHS & Dannevirke High School & $\mathrm{B} ?$ \\
\hline 234 & 31 & 49 & 57 & TSZ & Takapari Road & B \\
\hline 231 & 38 & 52 & 83 & MNGS & Mangaweka School & B \\
\hline 244 & 31 & 48 & 49 & ORCS & Ohakune Ruapehu College & $\mathrm{D}$ \\
\hline
\end{tabular}

Directional variation in attenuation is clearly evident in Figure 3 , with the rate of attenuation being much greater in the NW direction from the epicentre than in the SW direction. There is a distinct shadow-zone behind the Taupo Volcanic zone (TVZ), providing further evidence for anomalously high attenuation in that zone [9]. This effect accounts for the very low acceleration of $1.7 \mathrm{~mm} / \mathrm{s}^{2}$ at a distance of $308 \mathrm{~km}$ (Figure 5) that was recorded at Kuaotunu on the Coromandel Peninsula, involving a propagation path across the full width of the TVZ. 

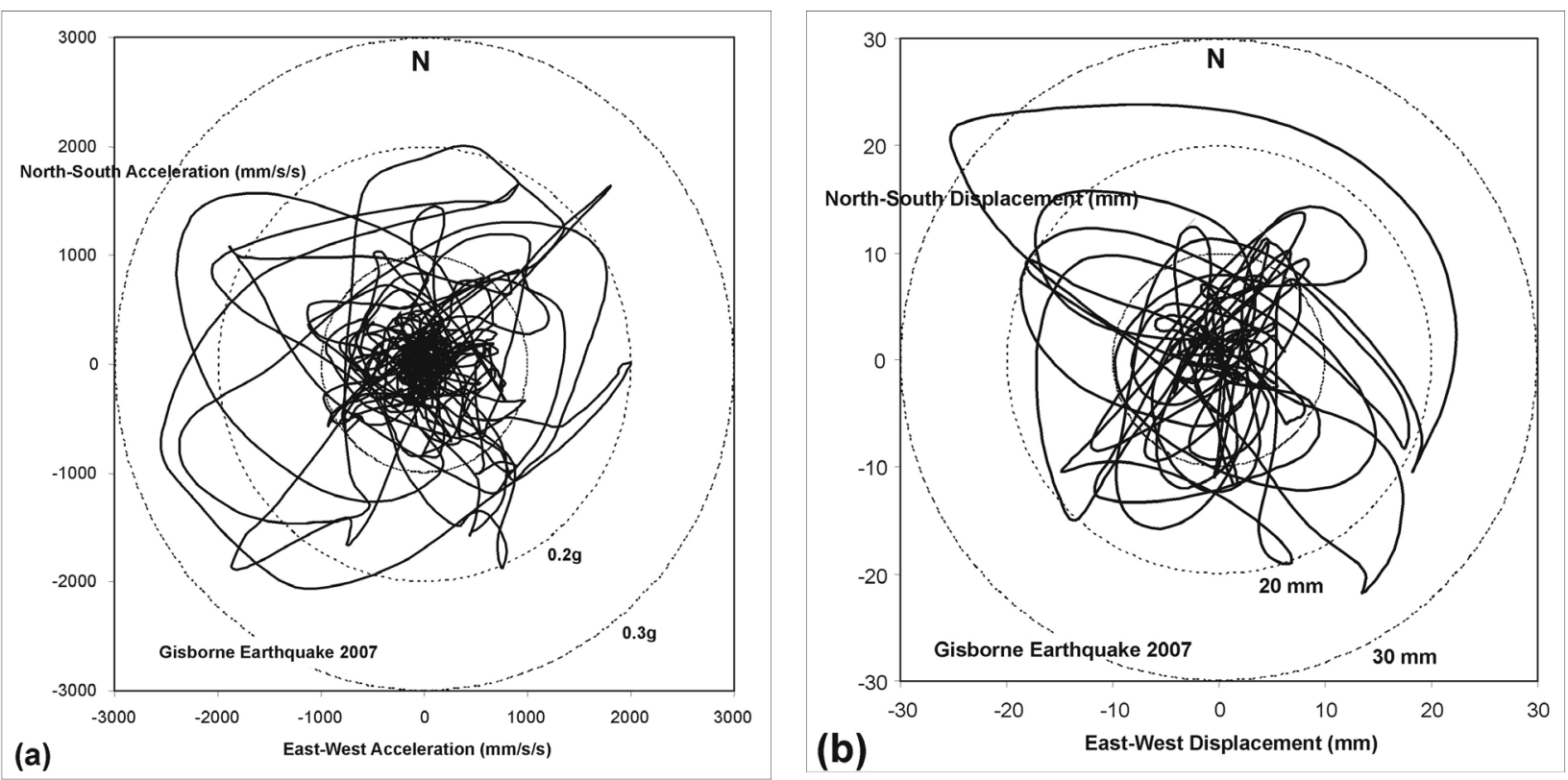

Figure 6: $\quad$ Polar plots of horizontal motions recorded at the 2ZG soft soil site in Gisborne, (a) accelerations, with 11 peaks exceeding $0.2 \mathrm{~g}$, and (b) displacements, with pronounced peaks along a NW-SE orientation, approximately parallel to Gladstone Road, the main street of Gisborne.

Gisborne city has now experienced recorded peak ground accelerations exceeding $0.25 \mathrm{~g}$ for the third time since 1966 . The two previous earthquakes producing similar levels of peak ground accelerations were at about half the distance and lower in magnitude by $0.5-1.1$ units. Polar plots of the horizontal accelerations showed that the larger magnitude and greater distance of Gisborne from the source in the 2007 earthquake was manifested in a greater number of strong cycles in the recorded motions than in the two previous earthquakes with similar PGAs. In the 2007 record at 2 ZG site in Gisborne city there were 11 peaks of about $0.2 \mathrm{~g}$ or greater (Figure $6 \mathrm{a}$ ). The $\mathrm{M}_{\mathrm{w}} 5.64$ plate interface earthquake of 4 March 1966 produced 8 peaks of about $0.2 \mathrm{~g}$ or greater, while the magnitude $\mathrm{M}_{\mathrm{w}} 6.19$ subducting-slab Ormond earthquake of 10 August 1993 showed only 3 cycles above or near $0.2 \mathrm{~g}$.

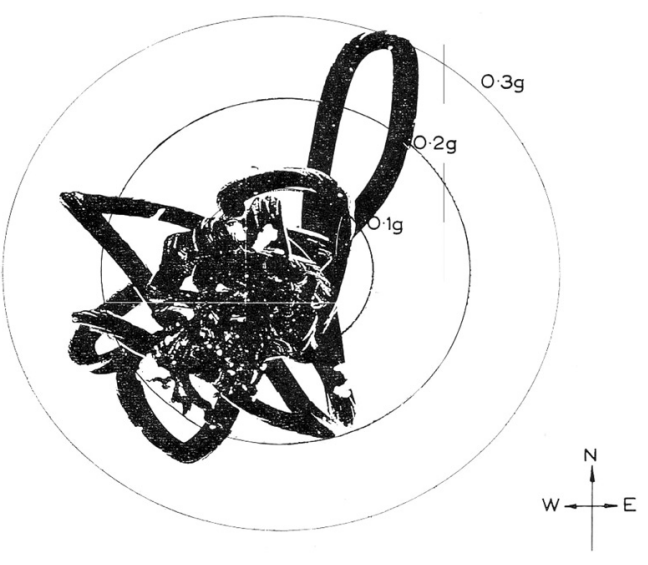

Figure 7: $\quad$ Polar plot of the horizontal acceleration in the 1966 earthquake from a scratch-plate acceleroscope, showing the strongest peak in the NNE direction. There were some indications that the worst damage was also aligned in this direction, almost orthogonal to the strongest motions in 2007.
A polar plot of the computed displacements (Figure 6b) reveals pronounced alignment along a NW-SE direction, which is nearly parallel to Gladstone Road, the main street of Gisborne. It is interesting to note that fallen parapets tended to be from walls perpendicular to Gladstone Road, which is what would be expected if the parapets were to be regarded as rocking bodies likely to topple in response to large displacement pulses. In contrast, the strongest acceleration in the 1966 earthquake was in the NNE direction (Figure 7). The only record was from a scratch-plate acceleroscope, from which it is not possible to double-integrate to calculate the displacement record. [10] commented that in 1966 "Displacement evident in building damage occurred at $90^{\circ}$ to the main street (Gladstone Road [...]), which is consistent with the direction of the peak acceleration of the instrumental record [...], but displacement also occurred parallel to Gladstone Road."

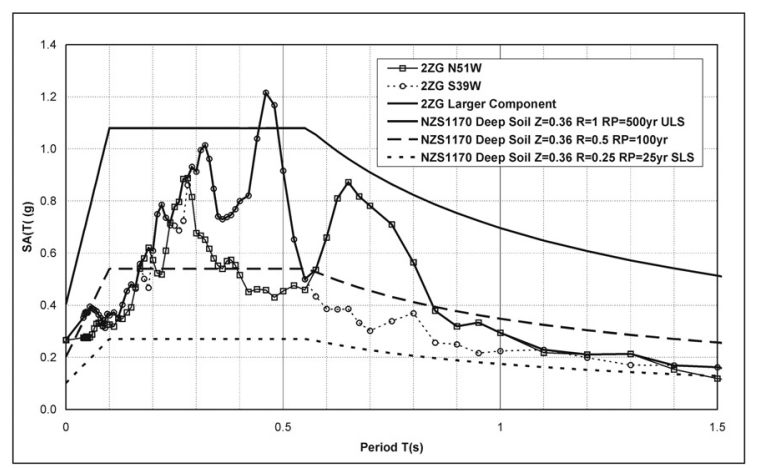

Figure 8:

Comparison of NZS1170 Deep or Soft Soil spectra for $R=1$ (500-year), $R=0.5$ (100-year) and $R=0.25$ (25-year) with the individual and stronger of the two horizontal components recorded at the $2 Z G$ site in the Gisborne central business area. 

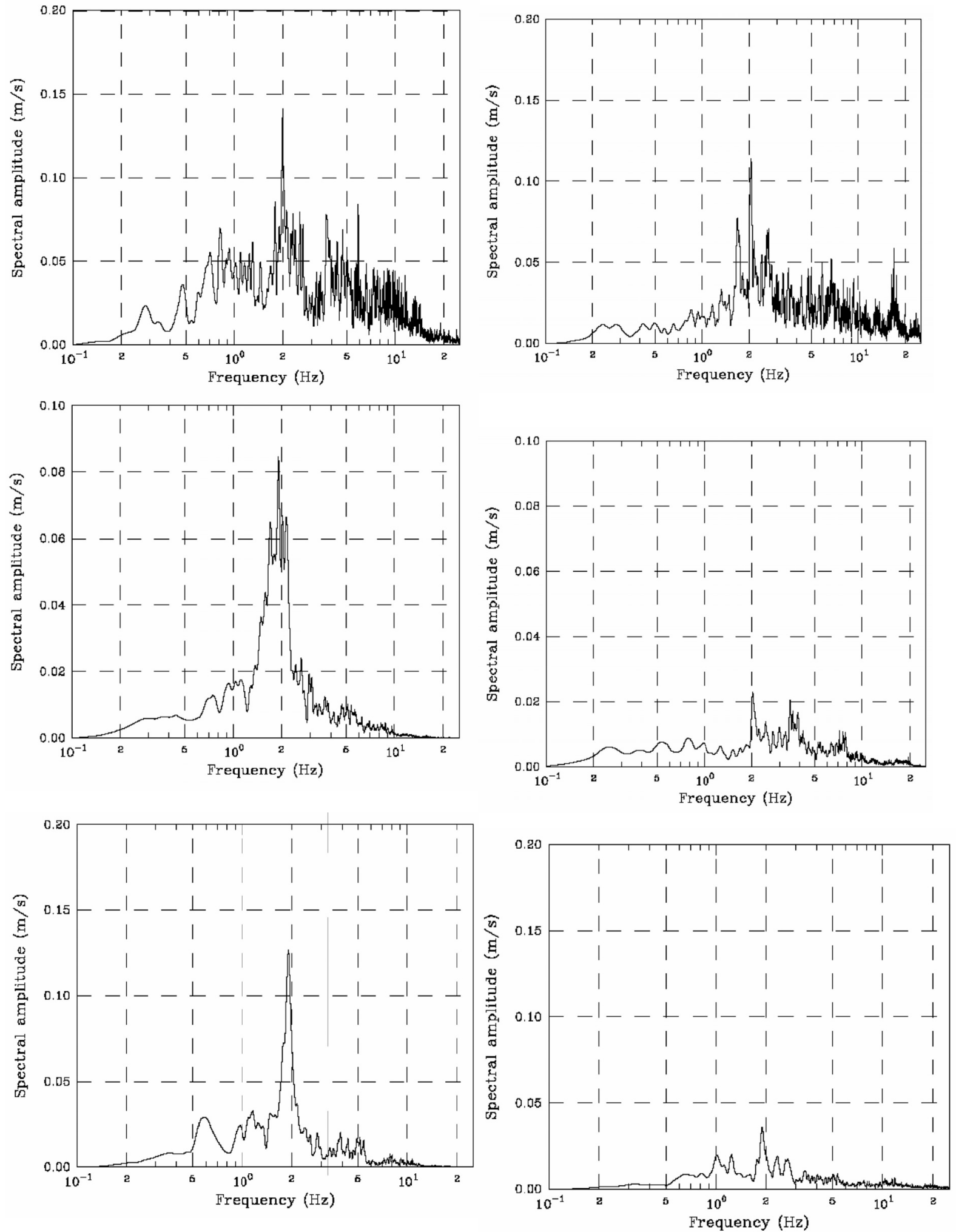

Figure 9: $\quad$ Fourier spectra of one horizontal (left-hand column) and vertical acceleration components for three stations (Kaweka, top; Taumarunui, middle; Petone, bottom) over a wide distance range, showing peaks at 2.0 $\pm \mathrm{Hz}$ (0.45-0.55s), possibly caused by $S$-to-P phase conversions in low-velocity material at the plate interface. 

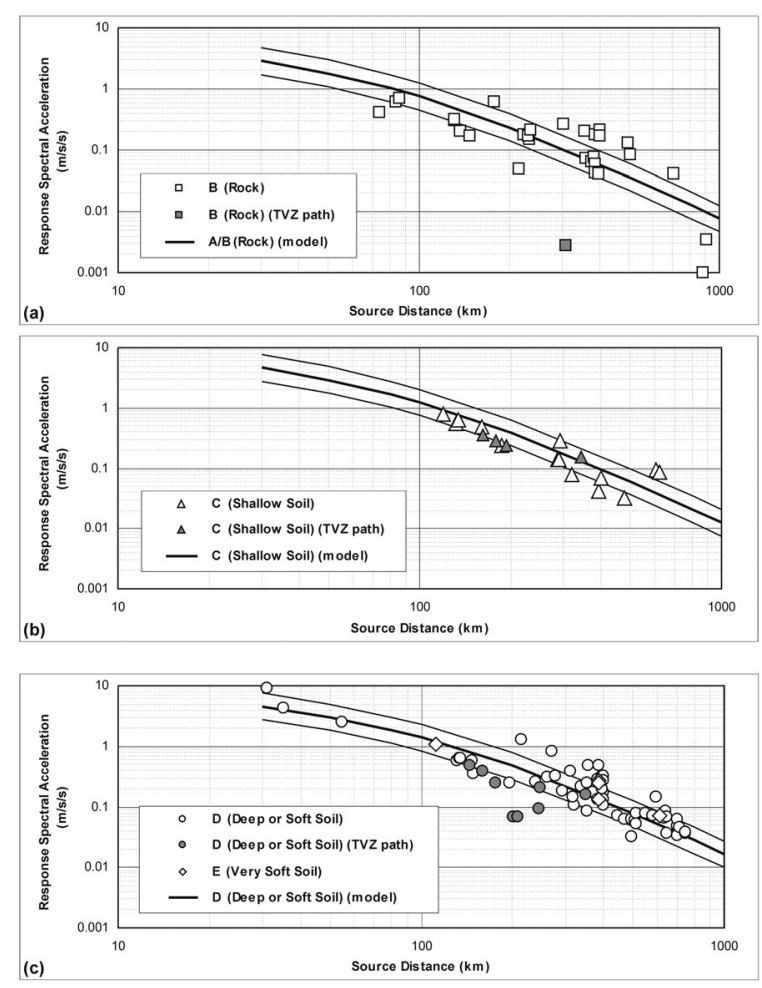

Figure 10: Comparison of data and models [8] for the attenuation of response spectral acceleration, for the case $0.5 \mathrm{~s}$ period and 5\% damping. Curves for the model include median estimates and \pm 1 standard deviation.

The recorded motions on deep soft soils in the Gisborne central business district exceeded current NZS1170.5:2004 design-level (return period factor $\mathrm{R}=1$, nominally 500 -year return period) motions for Class D Deep or Soft Soil Sites in a narrow period band around 0.45 s (Figure 8 ). They generally exceeded half code-level ( $\mathrm{R}=0.5,100$-year return period) motions over much of the period band up to $1 \mathrm{~s}$, but fell to much lower levels beyond this period band. Serviceability Limit State $(\mathrm{R}=0.25$, return period 25 years) motions were exceeded for all periods up to $1.5 \mathrm{~s}$. It is likely that pronounced site effects were involved in the strength of motions experienced in central Gisborne, for which the site classification is marginal between Class D and Class E Very Soft Soils. Unfortunately, there is no rock reference station in Gisborne at present to more clearly investigate this possibility.

Ground motions from this earthquake over much of New Zealand are characterised by a peculiarity; a strong spectral peak around $0.45-0.55 \mathrm{~s}$ (Figure 9), often occurring in the vertical component as well as at least one of the horizontal components. The widespread distribution of these spectral peaks suggests that they are related to a source effect or occur along the travel path close to the source region. One possibility is that $\mathrm{S}$ to $\mathrm{P}$ phase conversions occurred near the source as the radiating waves crossed a sharp velocity contrast. [11] modelled such conversions in a low-velocity layer at the plate interface in seven earthquakes within the subducted slab. If this explanation is correct, it is a systematic effect worthy of investigation to determine whether the frequency of similar peaks in future earthquakes can be predicted in terms of the location of the source with respect to the plate interface.

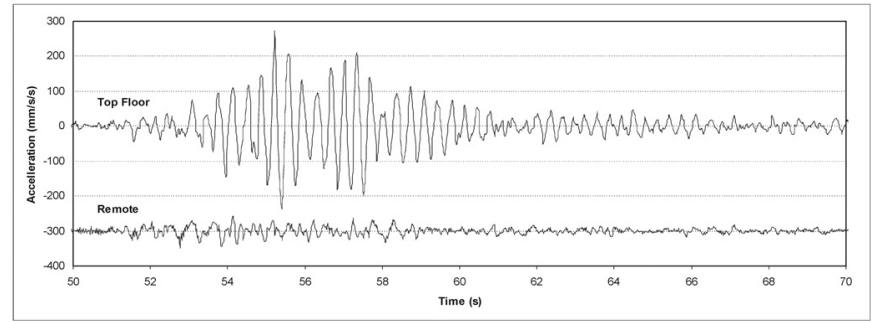

Figure 11: Comparison of remote and top floor accelerograms from the GNS Science building at Avalon. There is a significant level of structural amplification. Note that for clarity the remote accelerogram has been plotted with an offset of $-300 \mathrm{~mm} / \mathrm{s}^{2}$.

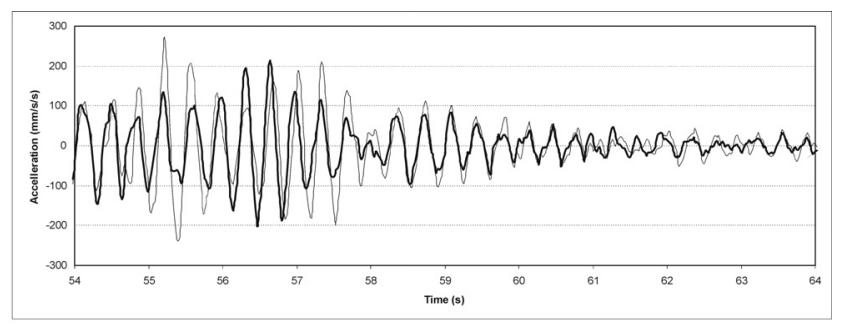

Figure 12: Comparison of the top floor accelerograms from opposite ends of the larger of two threestorey buildings at GNS Science, Avalon. The motions appear to be largely in phase, but there are some differences that will require detailed modelling for explanation.

The presence of this peak may have exacerbated the situation in Gisborne, with it being further enhanced in strong siteamplification around this period band, although previous earthquake motions recorded in Gisborne have been characterised by peak responses around $1 \mathrm{~s}$ rather than $0.45 \mathrm{~s}$ period.

The attenuation of response spectral acceleration is illustrated in Figure 10, in which recorded and modelled estimates of the 0.5 second, 5\% damped, acceleration responses are plotted separately for three ground classes. There is good agreement between the recorded and modelled accelerations, and the TVZ effect is clear for Class A and Class D soils.

A complete set of eight accelerograms was obtained from an array of accelerometers recently installed in the GNS Science building at Avalon, Lower Hutt. Preliminary inspection of the records indicates (a) that there was significant amplification between a remote ground site and the top floor of a 3-storey building, from 40 to $273 \mathrm{~mm} / \mathrm{s}^{2}$ peak acceleration (Figure 11), and (b) that motions at the opposite ends of the top of the same building were largely in-phase, but that there were differences in detail that may indicate a degree of torsional response (Figure 12). Detailed modelling of the accelerograms is planned.

\section{SOURCE CHARACTERIZATION}

\section{Moment tensor solution}

Centroid moment tensor (CMT) solutions for earthquakes with moment magnitude $\left(\mathrm{M}_{\mathrm{w}}\right)>4$ are now being routinely calculated for New Zealand earthquakes using regional broadband data from the GeoNet network [12]. The regional CMT for the Gisborne event was calculated by modelling the waveforms from seven stations bandpass filtered at $0.01-$ $0.033 \mathrm{~Hz}$ (Figure 13). The focal mechanism is a normal faulting mechanism (Strike $212^{\circ}$, dip $52^{\circ}$, rake $-116^{\circ}$ and strike $71^{\circ}$, dip $45^{\circ}$, rake $-60^{\circ}$ ) which is expected for events occurring 
within the subducted slab. The T-axis is oriented in a NW-SE direction which differs from other mechanisms in the region which tend to have an E-W trending T-axis. The moment (Mo) of $8.24 \times 10^{18} \mathrm{Nm}\left(\mathrm{M}_{\mathrm{w}} 6.6\right)$ and focal mechanism are consistent with the Global CMT Project and United States Geological Survey (USGS) moment tensor solutions calculated using teleseismic data. The depth of $24 \mathrm{~km}$ was determined by calculating solutions over a range of depths to find the depth with the highest variance reduction.

Only one aftershock was large enough to calculate a regional CMT, a $\mathrm{M}_{\mathrm{w}} 4.6$ event on 21 December 2007 (Figure 14). Three stations were used to calculate the aftershock CMT with the waveforms bandpass filtered at $0.04-0.08 \mathrm{~Hz}$. The aftershock was a normal faulting mechanism with a $\mathrm{T}$-axis rotated nearly $60^{\circ}$ counter clockwise relative to the mainshock and a depth of $33 \mathrm{~km}$. At depths greater than $33 \mathrm{~km}$ the focal mechanism rotates about $90^{\circ}$ which suggests that the solution may not be stable.
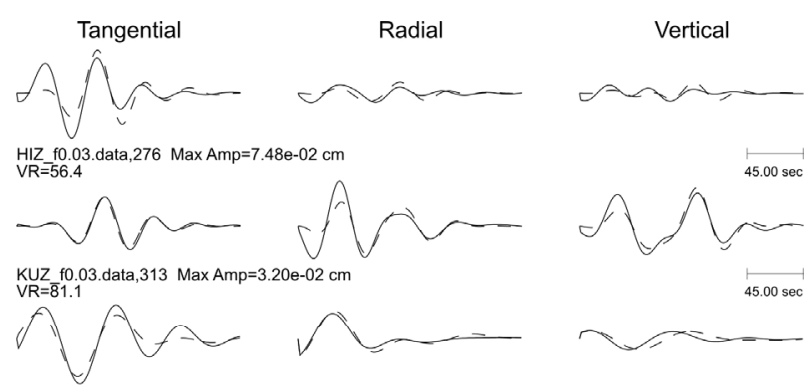

$M X Z$ fo.
$V R=\overline{8} 3.6$

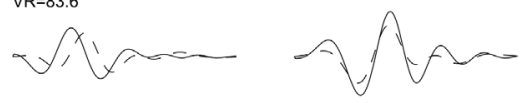

TSZ f0.03.data, 238 Max Amp $=3.36 \mathrm{e}-02 \mathrm{~cm}$

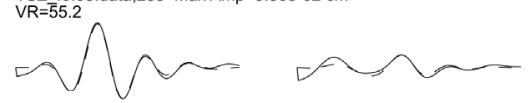

$\mathrm{VRZ}$ f0.03.data, $264 \mathrm{Max} A \mathrm{mp}=6.67 \mathrm{e}-02 \mathrm{~cm}$
$\mathrm{VR}=\overline{9} 1.0$
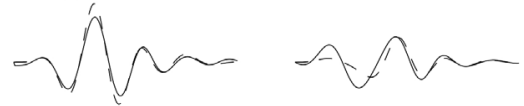

WAZ f0.03.data, 251 Max Amp $=3.53 \mathrm{e}-02 \mathrm{~cm}$
$\mathrm{VR}=\overline{81} .7$

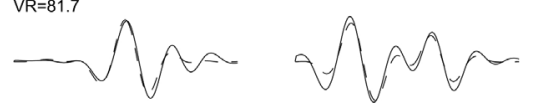

$W C Z$ f0. 03 .data, 310 Max Amp- $2.55 \mathrm{e}-02 \mathrm{~cm}$
$V R=90.4$

observed

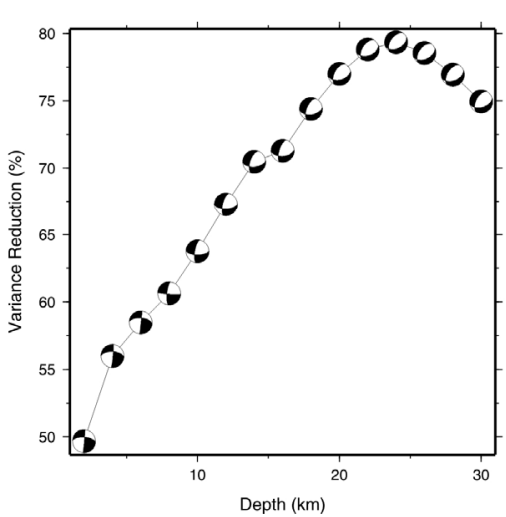

S/D/R: 212/52/-116 $71 / 45 /-60$

$\mathrm{M}: 8.24 \mathrm{E} 18 \mathrm{Nm}$

$M_{w}: 6.6$

$\%$ double-couple: 68

depth: $24 \mathrm{~km}$

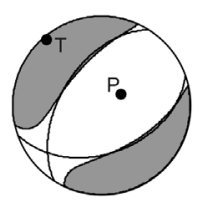

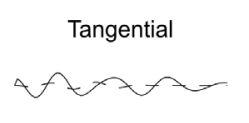

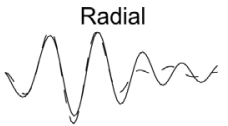

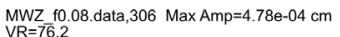

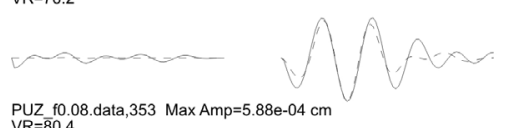

PUZ f0.08.data, 353 Max Amp $=5.88 \mathrm{e}-04 \mathrm{~cm}$

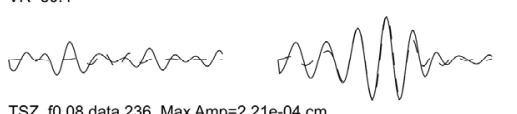

TSZ f0.08.data, $236 \mathrm{Max}$ Amp $=2.21 \mathrm{e}-04 \mathrm{~cm}$

observed

- - - - - synthetic

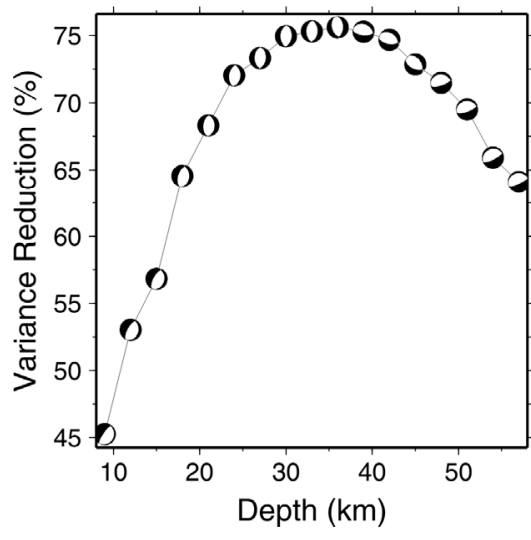

S/D/R: 2/47/-76

$161 / 45 /-105$

$M_{0}: 8.55 \mathrm{E} 15 \mathrm{Nm}$

$M_{w}: 4.6$

$\%$ double-couple: 4

depth: $33 \mathrm{~km}$

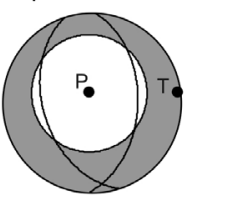

Figure 14: Regional CMT solution for the $M_{w} 4.6$ aftershock. Three stations were used in the solution with the observed data shown by the solid lines and the synthetics by the dashed lines. The variance reduction versus depth plot shows the focal mechanism rotating by about $90^{\circ}$ at depths greater than $33 \mathrm{~km}$.

Figure 13: Regional CMT solution for the $M_{w} \quad 6.6$ mainshock. Seven stations were used in the solution with the observed data shown by the solid lines and the synthetics by the dashed lines. The variance reduction versus depth plot shows the focal mechanism stabilizing to a normal faulting mechanism and around 15 $\mathrm{km}$ depth, with the best fit at $24 \mathrm{~km}$. 

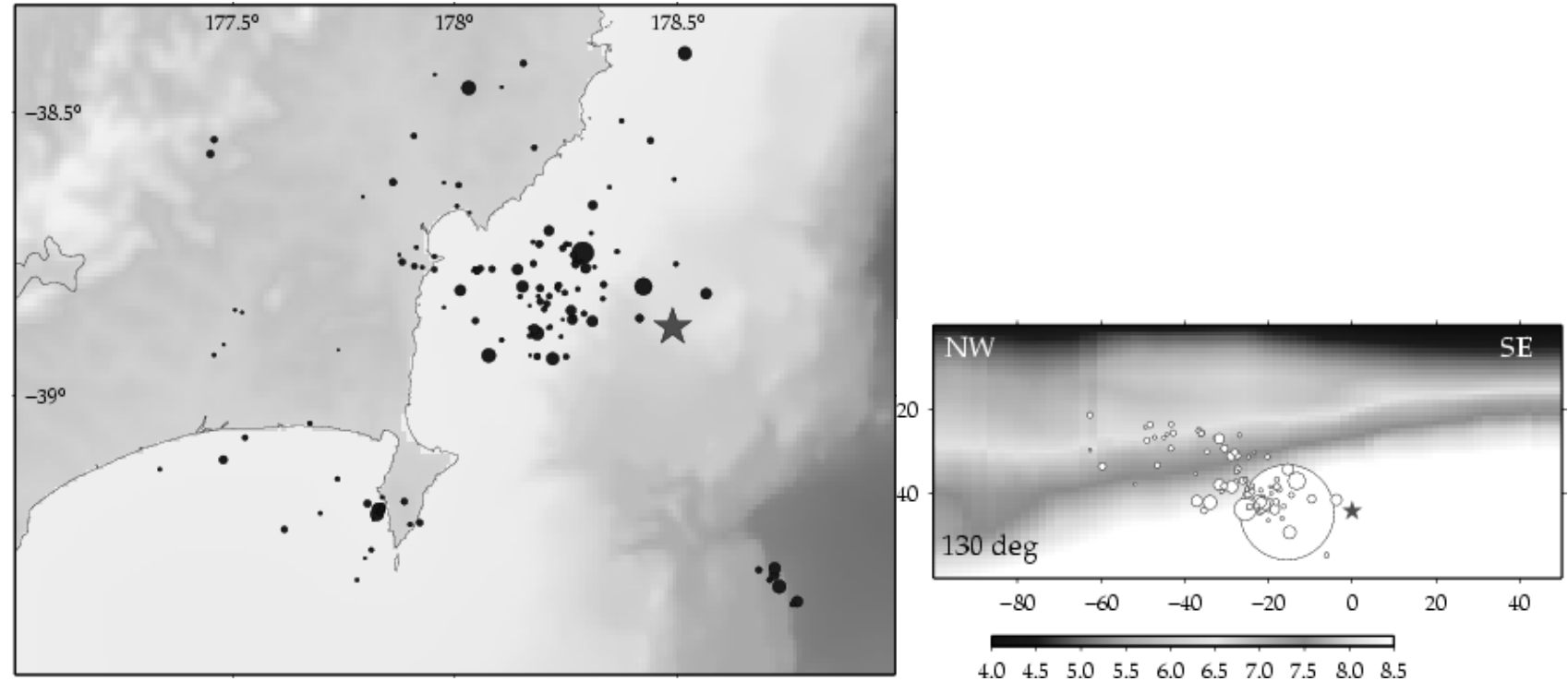

Figure 15: Left: the mainshock location determined by GeoNet is shown as a red star. 162 earthquakes subsequently relocated using a 3D velocity model, are shown as blue circles. Right: Relocated aftershocks projected onto a NW-SE (N130E) vertical plane oriented perpendicular to the strike of the Hikurangi subduction zone, with the event magnitudes represented by circle size, scaled logarithmically. The red star is the GeoNet location for the mainshock, while the largest open circle is the relocated mainshock location. The lateral shift in the estimated hypocenter is likely due to the use of the $3 D$ velocity model. Also shown is the P-wave velocity profile across the N130E line.

\section{Aftershock relocations}

GeoNet located 162 earthquakes in the greater Gisborne region between December 1st 2007 and January 8th, 2008. We subsequently used the DD tomography algorithm (tomoDD) of [13] for relocation of these aftershock events. The technique minimizes residuals between observed and calculated arrival-time differences for pairs of closely located earthquakes, while also minimizing the residuals of absolute arrival times. This approach builds on the DD location procedure of [14], which utilises the differential times of catalogue $\mathrm{P}$ and $\mathrm{S}$ phase times, as well as differential times derived from waveform cross-correlation. In addition to solving for the hypocentral parameters, the tomoDD algorithm solves for the 3-D velocity structure in the model region, requiring an additional smoothing parameter and damping parameter, as described by [13].

The full dataset comprised 642 absolute P-times, 221 absolute $\mathrm{S}$ phases, and 18,104 differential times. The P-wave velocities derived by [15] from earthquake and active-source data were used for the initial velocity model for the travel-time calculations. We interpolated their velocities onto a grid to encompass our aftershock zone.

Relocated events are plotted in Figure 15 (Left) in map view, while Figure 15 (Right) shows the relocated events projected onto a cross-section with a strike of N130E. The relocated events indicate a easterly-dipping fault plane, although there is only a weak constraint on the strike of this aftershock plane.

\section{GPS inversion}

The Gisborne earthquake produced surface displacements at coastal sites of up to $1 \mathrm{~cm}$ as measured on continuous GPS instruments of GeoNet. We inverted the surface displacements for the earthquake source parameters (centroid depth, width and length of plane, and slip amplitude) assuming uniform slip on a planar source embedded in an elastic half space. The location was set to the centre of the aftershock zone $\left(178.35^{\circ} \mathrm{E}, 38.87^{\circ} \mathrm{S}\right)$. We fixed the strike $=71$, dip $=46$ and rake $=-77$.

We solved for the centroid depth $(35 \mathrm{~km})$, along-strike length $(20 \mathrm{~km})$ and down-dip width $(23 \mathrm{~km})$ of the fault area $(460$ $\left.\mathrm{km}^{2}\right)$ and the average slip $(600 \mathrm{~mm})$ which gives a moment of $1.10 \times 10^{19} \mathrm{Nm}, \mathrm{M}_{\mathrm{w}}=6.63$ (Figure 16 (Left)).

The earthquake was followed by what we interpret as a slow slip event on the Hikurangi subduction interface. This event started on about the same day as the earthquake and proceeded in a manner similar to past slow slip events in the same region $[7,16]$. We modelled the spatial slip distribution as an elliptical source with a time history comprising overlapping triangular elements of 6 days duration each. The source region was north of the earthquake but seemed to abut the aftershock zone (Figure 16 (Right)). The slow slip lasted about 57 days with faster moment release in the beginning and then tailing off. The average slip was about $120 \mathrm{~mm}$ over an area of 2,450 $\mathrm{km}^{2}$. The moment of the slow slip was $1.17 \times 10^{19} \mathrm{Nm}, \mathrm{M}_{\mathrm{w}}=$ 6.65 . 

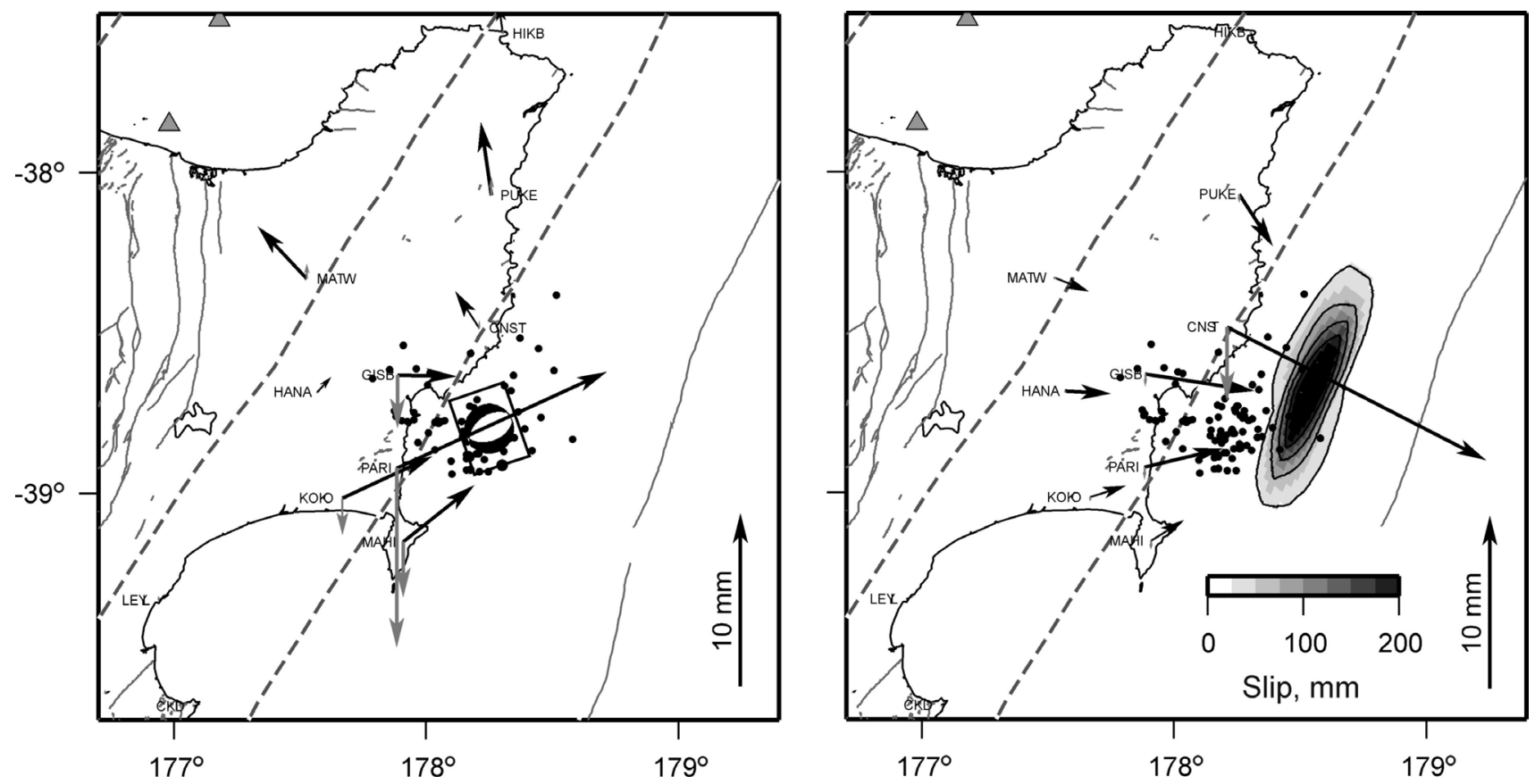

Figure 16: Left: GPS inversion solution for the main event and co-seismic displacement vectors (vertical displacement in grey and horizontal displacement in black) measured at continuous GPS GeoNet stations. Black circles are aftershocks. Right: GPS inversion solution of slip distribution on the fault plane for the slow slip event, and displacement vectors (vertical displacement in grey and horizontal displacement in black) measured at continuous GPS GeoNet stations resulting from the slow slip motion. Black circles are aftershocks.

Figure 17: Final slip distribution on a 40 by $60 \mathrm{~km}$ fault plane. The slip distribution is characterized by a small patch of very high slip (maximum $6.5 \mathrm{~m})$ near the hypocentre and a more diffuse and less well constrained patch of small amplitude slip (maximum $0.5 \mathrm{~m}$ ) further south and closer to the surface.

\section{Strong motion inversion}

To solve for a detailed slip and rupture time distribution of earthquake rupture, we inverted data from 12 strong motion sites of the GEONET network. Seismograms were band pass filtered between 0.01 and $0.1 \mathrm{~Hz}$ and integrated once into velocity data. We modelled one fault plane of 71 degree strike, 45 degree dip and 300 degree rake as defined both by moment tensor solution and aftershock relocation. The fault plane area is 40 by $60 \mathrm{~km}^{2}$. It is divided into $6002 \times 2 \mathrm{~km} 2$ subfaults. We inverted for 3 elliptical rupture area distributed randomly within the fault plane and with variable rupture velocity, slip and rake $[17,18]$.

Our best slip distribution (Figure 17) is characterized by an initial pulse of 6 by $10 \mathrm{~km}^{2}$ dimension, with a maximum slip of $6.5 \mathrm{~m}$ at $44 \mathrm{~km}$ depth on the main fault plane. There is also a wider source of maximum slip $0.5 \mathrm{~m}$ occurring later and closer to the surface. However this source is not very stable, and does not improve the data fit much more. The moment value calculated for that solution is $1.65 \times 10^{19} \mathrm{Nm}$, which is a bit high for a $\mathrm{M}_{\mathrm{w}} 6.6$ event. We also computed for that event a stress drop value of $17 \mathrm{MPa}$. This value of stress drop is very high but expected for an intraplate-type event. The high stress drop is also consistent with observations of very energetic waves for near field stations and heavy damage in the nearby city of Gisborne.

\section{SAR Interferometry}

Interferometric studies [19, 20] were performed using L-band ALOS PALSAR synthetic aperture radar data (path 322, frames 6390-6400) and topography was removed using the SRTM 90 meters resolution digital elevation model. Quadratic trend was modelled and removed from the interferograms in order to correct long wave-length signal (orbital inaccuracies and tropospheric noise). Figure 18a shows a direct modelling [21] of permanent surface deformation caused by the earthquake using simple fault parameters (strike 71,dip 45, rake 300 , slip $2 \mathrm{~m}$ on $8 \times 12 \mathrm{~km}$ plane at $40.5 \mathrm{~km}$ depth). A signal (light blue colour at the south), of approximately similar magnitude and shape to that predicted by the model, was observed on three interferograms with time spans covering the earthquake: 20070108-20080111 (Figure 18b), 2007101120080111 (Figure 18c) and 20070826-20080111 (Figure 18d); however small scale tropospheric heterogeneities are also present and significantly complicate the interpretation. 

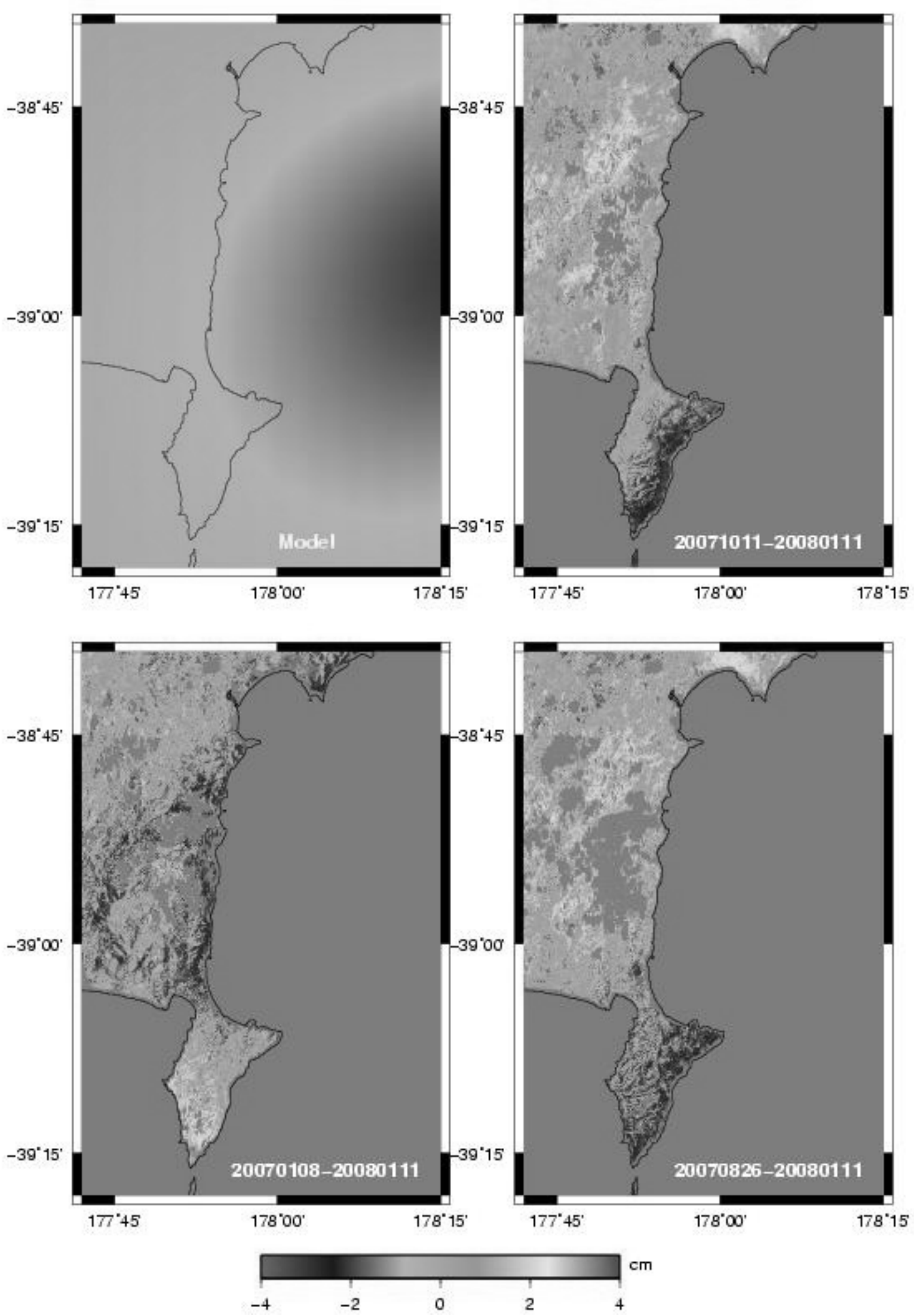

Figure 18: $\quad$ Results of direct modelling (a) and unwrapped geocoded differential interferograms 20070108-20080111 (Figure b), 20071011-20080111 (Figure c) and 20070826-20080111 (Figure d). Signal coloured in blue in the southern part of the image is anticipated to be caused by the Gisborne earthquake 


\section{CONCLUSION}

The separate geophysical studies converge to the conclusion that the $M_{w}$ 6.6 Gisborne earthquake is a complex event. Strong motion data show very high amplitude acceleration records exceeding $0.1 \mathrm{~g}$ at three locations (reaching $0.28 \mathrm{~g}$ in Gisborne city). Spectral analysis also shows a $2 \mathrm{~Hz}$ peak on all the records, likely to be linked to the source itself or to a propagation path effect close to the source. The source analysis reveals an impulsive event that occurred at $40 \mathrm{~km}$ depth within the downgoing slab of the Hikurangi subduction zones, with damaging effects in the nearby city of Gisborne. Another complex effect associated with this event was the triggering of a slow slip event offshore. Further studies of this complex but well recorded event will provide a better understanding of the regional tectonic context.

\section{ACKNOWLEDGEMENT}

The authors acknowledge the EQC via the GeoNet Project and the Geological Hazards and Society research programme (contract CO5X0402) of the Foundation for Research Science and Technology for funding in support of this research. We acknowledge the New Zealand GeoNet project for providing data used in this study. The interferograms incorporate data which is (C) Japan Aerospace Exploration Agency ("JAXA") and the Japanese Ministry of Economy, Trade and Industry ("METI") (2007). The ALOS PALSAR data has been used in this work with the permission of JAXA and METI and the Commonwealth of Australia (Geoscience Australia) ("the Commonwealth"). JAXA, METI and the Commonwealth have not evaluated the data as altered and incorporated within this work, and therefore give no warranty regarding its accuracy, completeness, currency or suitability for any particular purpose. Some figures were made using Generic Mapping Tools free software [Wessel and Smith, 1998]. We thank Russell Robinson and Mark Stirling for thoroughly reviewing this manuscript.

\section{REFERENCES}

1. Reyners, M. and McGinty, P., 1999. Shallow subduction tectonics in the Raukumara Peninsula, New Zealand, as illuminated by earthquake focal mechanisms. Journal of Geophysical Research B: Solid Earth, 104(B2): 30253034.

2. Barker, D.H.N., Sutherland R., Henrys S. and Bannister S., manuscript submitted to Tectonics. Geometry of the Hikurangi subduction thrust and upper plate, North Island, New Zealand.

3. Wallace, L.M., Beavan, J., McCaffrey, R. and Darby, D., 2004. Subduction zone coupling and tectonic block rotation in the North Island, New Zealand, Journal of Geophysical Research, 109, doi:10.1029/2004JB003241.

4. Doser, D.I. and Webb, T.H., 2003. Source parameters of large historical (1917-1961) earthquakes, North Island, New Zealand. Geophys. J. Int., 152, 795-832.

5. Webb, T. and Anderson, H., 1998. Focal mechanisms of large earthquakes in the North island of New Zealand : slip partitioning at an oblique active margin. Geophys. $J$. Int., 134, 40-86.

6. Reyners, M., McGinty, P. and Gledhill, K., 1998. The Ormond, New Zealand earthquake of 1993 August 10: rupture in the mantle of the subducted Pacific plate, New Zealand Journal of Geol. and Geophys., 41, 179-185.

7. Douglas, A., Beavan, J., Wallace, L., Townend, J., 2005. Slow slip on the northern Hikurangi subduction interface, New Zealand Geophysical Research Letters, 32, doi:10.1029/2005GL023607.
8. McVerry, G.H., Zhao, J.Z., Abrahamson, N.A. and Somerville, P.G. 2006. New Zealand acceleration response spectrum attenuation relations for crustal and subduction zone earthquakes. Bulletin of the New Zealand Society for Earthquake Engineering, 39(1): 1-58.

9. Eberhart-Phillips, D., Reyners, M. Chadwick, M. Stuart, G., 2008. Three-dimensional attenuation structure of the Hikurangi subduction zone in the central North Island, New Zealand. Geophys. J. Int., 174, 418-434.

10. Strachan, C.M., and Glogau O.A., 1969. Report on damage in the Gisborne earthquake 1966, Bulletin 194, New Zealand Department of Scientific and Industrial Research.

11. Eberhart-Phillips, D. and Reyners, M., 1999. Plate interface properties in the northeast Hikurangi subduction zone, New Zealand, from converted seismic waves. Geophys. Res. Lett., 26: 2565-2568.

12. Ristau, J., 2008. Implementation of routine regional moment tensor analysis in New Zealand, Seism. Res. Lett., 79, 400-415, doi: 10.1785/gssrl.79.3.400.

13. Zhang, H. and Thurber, C., 2003. Double-difference tomography: the method and its application to the Hayward Fault, California, Bull. Seismol. Soc. Am. 93 (2003), pp. 1875-1889.

14. Waldhauser, F. and Ellsworth, W. L. 2000. A doubledifference earthquake location algorithm: Method and application to the northern Hayward fault, California, Bull. Seismol. Soc. Am., 90, 1353-1368.

15. Reyners, M.E., Eberhart-Phillips, D., Stuart, G., Nishimura, Y., 2006. Imaging subduction from the trench to $300 \mathrm{~km}$ depth beneath the central North Island, New Zealand, with Vp and Vp/Vs. Geophysical journal International, 165(2), 565-583.

16. Beavan, J., Wallace, L., Douglas, A., Fletcher, H., and Townend, J., Slow slip events on the Hikurangi subduction interface, New Zealand, Dynamic Planet, Monitoring and Understanding a Dynamic Planet with Geodetic and Oceanographic Tools, IAG Symposium, Cairns, Australia, 22-26 August, 2005, Series: International Association of Geodesy Symposia, Tregoning, Paul; Rizos, Chris (Eds.), Vol. 130, 438-444, (2007).

17. Francois-Holden, C., Di carli, S., Sladen A. and Madariaga R., 2008. Non linear kinematic source inversion of the 2000 Tottori, Japan earthquake submitted Geophys. Res. Letters.

18. Peyrat, S. and Favreau, P. Kinematic and spontaneous rupture models of the 2005 tarapaca intermediate depth earthquake-submitted. Geophys. J. Int.

19. Massonnet, D. and FEIGL, K., 1998, Radar interferometry and its application to changes in the Earth surface: Reviews of Geophysics, 36, 441-500.

20. Rosen, P., Hensley, P., Joughin, I., Li, F., Madsen, S., Rodriguez, E. and Goldstein, R., 2000, Synthetic aperture radar interferometry: Proceedings of the IEEE, 88, 333382.

21. OKADA, Y., 1992, Internal deformation due to shear and tensile faults in a half-space: Bulletin of the Seismological Society of America, 82, 1018-1040.

Internet resource for sand boils observations:

http://www.gisborneherald.co.nz/Default.aspx?s=3\&s1=2\&id $=812836 \mathrm{~d} 947 \mathrm{~b} 9455 \mathrm{c} 90 \mathrm{ed} 8017 \mathrm{ace} 91 \mathrm{bf3}$. 